\title{
contenporaneity
}

Vol 9, No 1 (2021) | ISSN 2153-5914 (online) | DOI 10.5195/contemp/2021.327

http://contemporaneity.pitt.edu

\section{how the light gets in}

Herbert F. Johnson Museum of Art, Cornell University

\author{
Adriana Miramontes Olivas
}

\section{Exhibition Review}

Exhibition Schedule: Herbert F. Johnson Museum of Art, Cornell University, Ithaca NY, September 7 - December 8, 2019

\section{About the Author}

Adriana Miramontes Olivas is a PhD candidate in the History of Art and Architecture Department at the University of Pittsburgh. Her dissertation focuses on contemporary artists who visit the Mexico-US border to examine issues such as feminicide and juvenicidios to protest a neoliberal global apparatus that, in conjunction with the state, render the lives of workers, women, and youth ungrievable and expendable. Her research areas include global contemporary art, Mexican art, border studies, and feminist studies. 


\section{how the light gets in Herbert F. Johnson Museum of Art, Cornell University}

"REUNITE" was inscribed on a giant yellow street sign placed on the façade of the Herbert F. Johnson Museum of Art, Cornell University (Fig. 1). Presented as part of the exhibit how the light gets in, on view from September 7 to December 8, 2019, in Ithaca, New York, Ronald Rael and Virginia San Fratello's artwork, Reunite (2019), sent a strong, clear message to both visitors and non-visitors to the museum. The sign, in which the silhouettes of a man and a woman appear running toward a girl, refers to the controversial policies that have separated families in the United States based on birthright citizenship. Reunite protests such legal and violent practices, which discriminate based on migratory status and have not only created chaos within the immigration system but also left many unaware of the location of their families, imprisoned, or exiled. Rael and San Fratello's Reunite challenges what has become a normalized term-citizenship-and invites viewers to consider more flexible definitions of belonging that emphasize our common humanity and solidarity, as opposed to allegiance to the modern nation-state. ${ }^{1}$

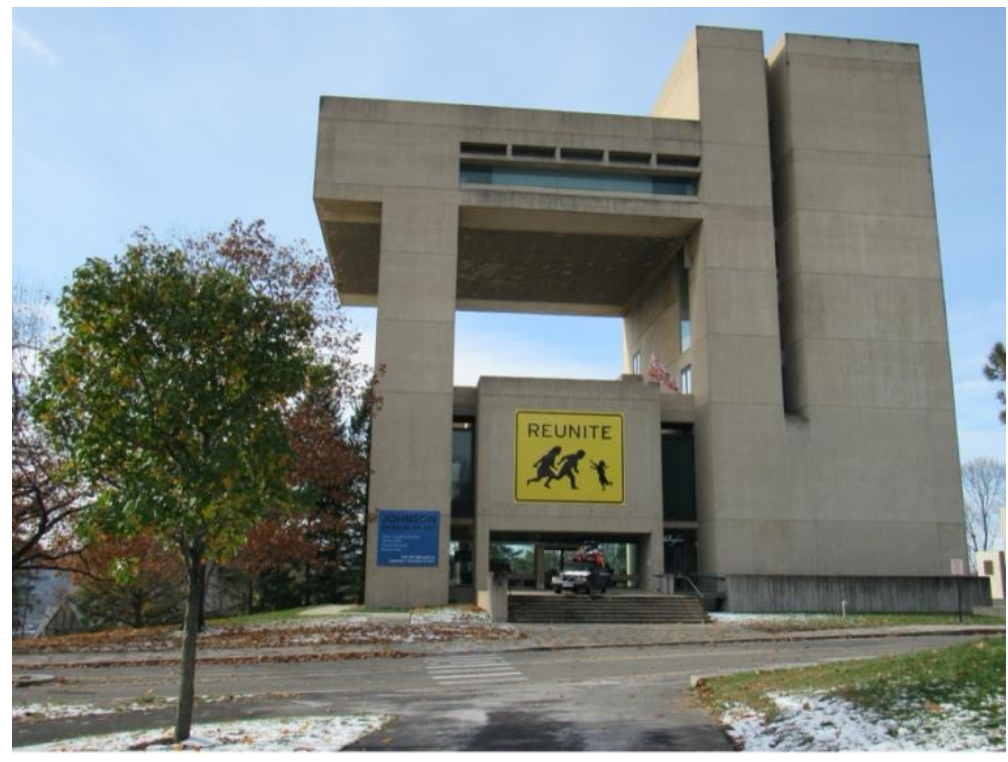

Figure 1 Herbert F. Johnson Museum of Art, Cornell University. November 2019. Installation view of four artworks in the exhibition how the light gets in. Lucy + Jorge Orta, Antartica Flag-La Villete, 2014,

inkjet on polyamide, edition of 40; Tavares Strachan, I Belong Here, 2013 white neon and two transformers, edition of $9+2$ AP; Ronald Rael and Virginia San Fratello, Reunite, 2019, vinyl; Manaf Halbouni, Nowhere is Home, 2015-ongoing, mixed media (Photo: Author)

\footnotetext{
${ }^{1}$ Achille Mbembe defines our contemporary condition as "a time of planetary entanglement." Characterized by ideas of a perfect security, a process of borderization, and a penitentiary geography, thousands of people have been denied freedom and endured a restricted mobility. Deprived of their human dignity, many remain in limbo in refugee camps, migrant camps, and detention centers. In other words, many have been condemned by the accident of their birthplace. Mbembe invites us to confront these injustices and instead to recognize our common humanity. Mbembe also encourages us to "imagine the impossible-the abolition of borders, that is to say, giving all inhabitants of the Earth-human and nonhuman alike-the inalienable right to freedom of movement on this planet?" Achille Mbembe, Necropolitics, trans. Steven Corcoran (Durham and London: Duke University Press, 2019$), 104$.
} 
Reunite was one of many artworks in how the light gets in that presented a strong call for denationalizing citizenship, undermining political borders, and undoing imperialism. ${ }^{2}$ On view at the Johnson Museum of Art were a total of fifty-nine artists, three collectives, and more than one hundred artworks, including installations, banners, prints, and video art, distributed around the museum's galleries, hallways, staircases, and façade. The exhibit provided an overwhelming but emotionally charged and conceptually rich experience. The artists were mostly born in the Global South, in places such as Venezuela, Chile, Argentina, Ghana, Benin, Eritrea, Iran, Iraq, Syria, China, and the Philippines, yet live or work in the Global North, in Germany, England, France, and South Korea or the United States, among other nations. These artists included Manaf Halbouni, Sobia Ahmad, Jorge Méndez Blake, Aram Han Sifuentes, and Esperanza Mayobre. The US-based artists with works in the exhibition were Zoe Leonard, Catherine Opie, and Ronald Rael and Virginia San Fratello. The collectives included in the show were Postcommodity, Peng! Collective, and Forensic Oceanography (Forensic Architecture). ${ }^{3}$

The prevailing message of how the light gets in is the need to move beyond the binary of citizen/noncitizen and to subvert a statist notion of citizenship in favor of an open, pluralized concept that acknowledges others as co-citizens in a shared world. ${ }^{4}$ Other themes seen throughout the exhibit include collective resistance, the hardships of seeking asylum, being a refugee, or going in exile, and the desolate landscapes and threatening oceans encountered when fleeing. The museum's galleries were organized according to bare life, the institutionalization of migration and identity documents, and the structural violence of borders ${ }^{5}$-themes echoed in current scholarship and publications by Ariella Aïsha Azoulay, Judith Butler, Saskia Sassen, and Benedict Anderson, among others.

Publicity for the exhibit announced hope, empathy, and vulnerability as major themes. According to official sources, other topics of the exhibit were displacement, mobility, and the refugee crisis. Curated by Andrea Inselmann, the exhibit subverted notions of home as well as immigration policies. ${ }^{6}$ Yet, despite the exhibition's emphasis on the violence of escaping one's

${ }^{2}$ According to Ariella Aïsha Azoulay, undoing imperialism means unlearning imperial rights to restore disabled rights to those whose rights have been smashed, ignored, or forbidden. Imperial rights include the right to discover, appropriate, and dominate other worlds. By unlearning imperialism, we can claim our right not to be perpetrators, but to act along and with one another and to care, together, for the shared world. By unlearning imperial/modern citizenship, we have an opportunity to side with others who have suffered and to advocate for their cause. See Ariella Aisha Azoulay, Potential History: Unlearning Imperialism (London: Verso, 2019).

3 The full list of artists included Saâdane Afif, Sobia Ahmad, Shiva Ahmadi, John Akomfrah, Sama Alshaibi, Mounira Al Solh, Kader Attia, Aziz + Cucher, Radcliffe Bailey, Rina Banerjee, Keren Benbenisty, Dawoud Bey, Jorge Méndez Blake, Phoebe Boswell, Andrea Bowers, Tania Bruguera, Margarita Cabrera, Yoan Capote, Enrique Chagoya, Gohar Dashti, Lois Dodd, Willie Doherty, Fidencio Fifield-Pérez, Meschac Gaba, Cyprien Gaillard, Guillermo Galindo, John Gerrard, Mohamad Hafez, Manaf Halbouni, Mona Hatoum, Alfredo Jaar, Hayv Kahraman, Zoe Leonard, Glenn Ligon, Hew Locke, Teresa Margolles, Elisabeth Mase, Esperanza Mayobre, Richard Misrach, Fiamma Montezemolo, Richard Mosse, Yoshua Okón, Catherine Opie, Lucy + Jorge Orta, Driss Oüadahi, Dawit L. Petros, Ronald Rael and Virginia San Fratello, Jolene K. Richard, Steve Henhawk, Waylon Wilson, Yinka Shonibare, Aram Han Sifuentes, Shahzia Sikander, Tavares Strachan, Stephanie Syjuco, and Ai Weiwei.

${ }^{4}$ According to Azoulay, co-citizenship denies racial, gender, and national categorizations. Azoulay adds, "We should contest the right, that a minority of founders acquired for themselves, to differentiate people from others with whom they are governed and to delegate to their descendants the continuance of this legacy." Azoulay, Potential History, 268.

5 Giorgio Agamben uses the term "bare life" in reference to lives that are unprotected, deprived of human rights, lives that may be, in Agamben's words, "killed without the commission of homicide." Giorgio Agamben, Homo Sacer: Sovereign Power and Bare Life, trans. Daniel Heller-Roazen (Stanford: Stanford University Press, 1995), 159.

6 "how the light gets in," At the Johnson: The Member's Newsletter of the Herbert F. Johnson Museum of Art (Fall 2019): 5-10. 
"home" and the often-encountered rejection and aggression upon arrival at borders of "safer" countries, it did not sensationalize the topics and avoided explicit imagery that could alienate viewers. $^{7}$ Still, the undermining of political borders resonated throughout the exhibit, inviting viewers to reflect on their constructed nature and the possibility of a different reality. As cultural historian Benedict Anderson shows, the nation is not only created but enforced and promoted by the rewriting of history, changes in the educational system, the adoption of specific languages, and state propaganda. ${ }^{8}$ In a similar way, notions of belonging and modern citizenship are not only imagined, but also enacted, performed, and imposed. how the light gets in invites viewers to acknowledge broader definitions of home, community, and engagement with each other. ${ }^{9}$

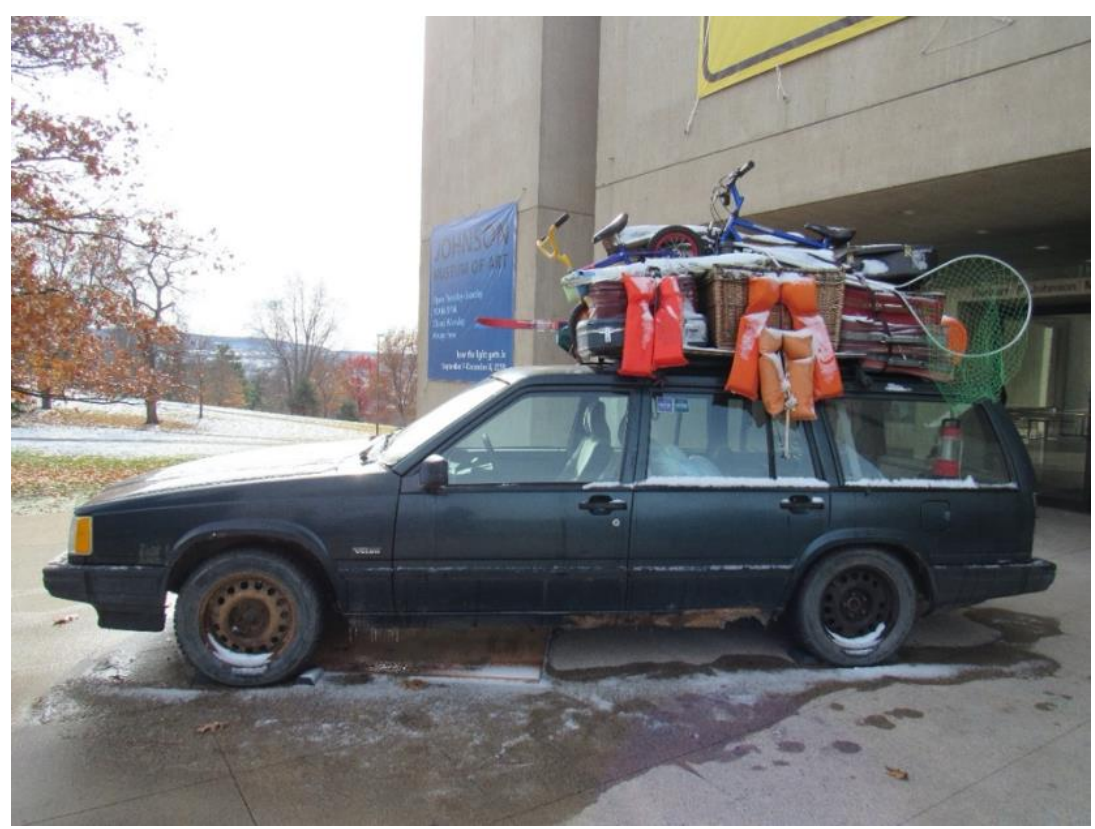

Figure 2 Manaf Halbouni, Nowhere Is Home, 2015-ongoing. Mixed media (Photo: Author)

The challenges refugees and immigrants experience were communicated on the façade of the Johnson Museum of Art directly beneath the word "Reunite." In Nowhere Is Home (2015ongoing), Manaf Halbouni attached personal belongings, including suitcases, toys, and bicycles to a black Volvo (Fig. 2). The precious possessions also incorporated life vests to illustrate the

\footnotetext{
7 Judith Butler references the violence encountered by immigrants who are labeled as a threat to the nation by violent states, institutions, and politicians. As Butler writes, "At risk of suffering violence and destruction is imagined to be the condition of the state that defends itself against migrants. And yet the violence is state violence, fueled by racism and paranoia, and directed against the migrant population." Judith Butler, The Force of Nonviolence: An Ethico-Political Bind (London, New York: Verso, 2020), 142146.

8 Benedict Anderson, Imagined Communities (London, New York: Verso 2006).

${ }^{9}$ As Butler explains, our constitutive interdependency means that violence against others is violence against the self. Violence against immigrants, refugees, or those seeking exile will never guarantee equality and freedom in the "nation." There must be a unified front against racism, xenophobia, misogyny, and other forms of hatred because we are all interconnected, and we have postnational obligations. In Butler's words, global obligations are "obligations that are globally shared and ought to be considered binding-they cannot be reduced to obligations that nation-states have toward one another. They would have to be post-national in character, traversing borders and navigating their terms, since populations at the border or crossing the border (stateless people, refugees) are included in the larger network of interrelationships implied by global obligations." Butler, Force of Nonviolence, 47.
} 
dangers of leaving one's home and the desire for survival. A sticker on the car's back asks, "gas or water?" demonstrating the tough decisions often made by those escaping hardships. Immediately above Reunite and to the right side, a flag on the façade of the Johnson Museum of Art advocates for camaraderie and the erasure of political borders. In Antarctica Flag -La Villete (2014) by Lucy + Jorge Ota, miniature images of flags from a variety of countries intermingle, undermining any hierarchies and the notion of nationalism. As the flags blur and merge into each other, they suggest a process of transformation and obliteration. Near the entrance of the museum, and below Lucy + Jorge Ota's flag on the window panel, Tavares Strachan's message I Belong Here (2013) further promotes the idea of membership within a community regardless of violent laws that seek to exclude. Strachan's neon sign I Belong Here creates ambiguity and raises questions regarding the "Here." This "Here" is everywhere and nowhere, accentuating the need for more inclusive policies unattached to territories.

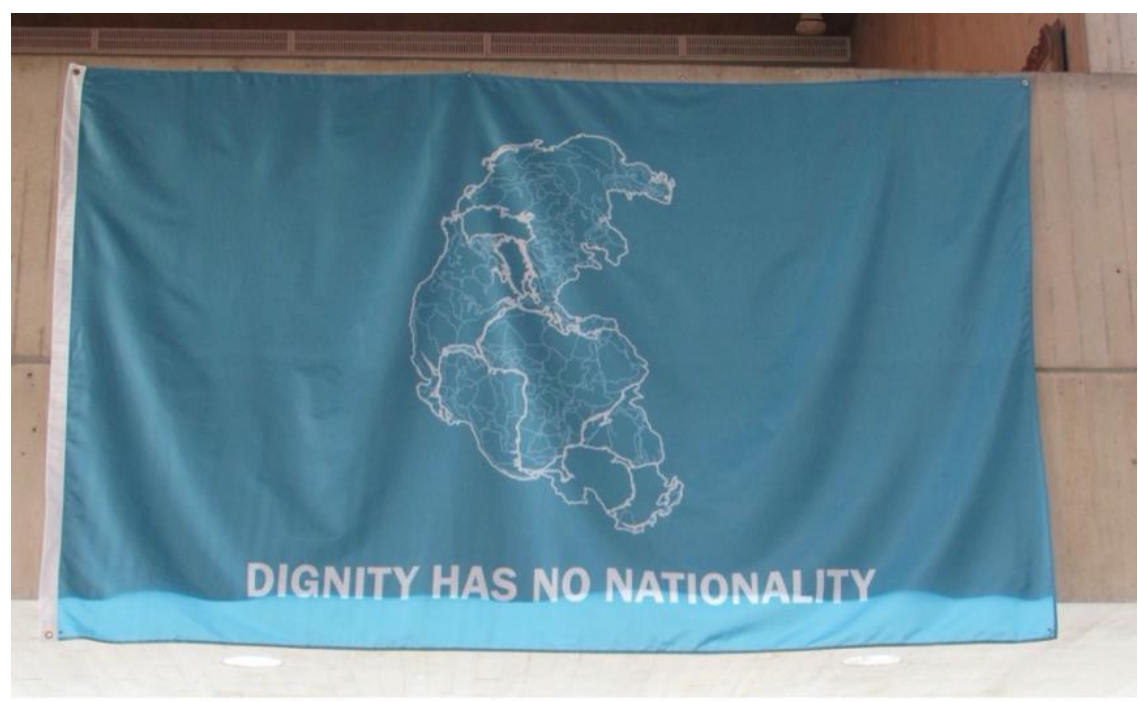

Figure 3 Tania Bruguera, Dignity has no nationality (2017). Nylon (Photo: Author)

The case for denationalized citizenship in how the light gets in is further conveyed upon entering the Johnson Museum of Art. Right above the front desk, Tania Bruguera's banner Dignity has no nationality (2017) shows the supercontinent Pangaea on which man-made political borders were nonexistent (Fig. 3). Other banners within the museum's halls were created by visitors in a gallery that emphasized collective resistance and empowered participants (Fig. 4). In this area, the museum offered a banner-making station as well as a lending library from which activists could borrow banners to attend protests or participate in street demonstrations. ${ }^{10}$ This aspect of the exhibit emphasized a form of citizenship presented by Linda Bosniak in which citizenship is defined as active engagement in society. ${ }^{11}$ The bannermaking station can also be interpreted according to Ariella Aïsha Azoulay's ideas on the right

\footnotetext{
10 The museum also held a banner-making workshop led by artist Aram Han Sifuentes on two occasions on September 12 and November 13, 2019. Other programming in conjunction with this exhibit is listed in "how the light gets in," At the Johnson: The Member's Newsletter of the Herbert F. Johnson Museum of Art (Fall 2019): 5-10.

11 According to Linda Bosniak, citizenship requires legal recognition as well as the enjoyment of rights, participation in the political life of the community, and a sense of community membership. While she acknowledges that citizenship remains a national affair, she also demonstrates that the term is contested and subject to change. In Bosniak's words, "At least some politically and socially-based-non-state communities-including some that have taken form across national boundaries-can serve as sites of citizenship identity and solidarity." Linda Bosniak, "Citizenship Denationalized," Indiana Journal of Global Legal Studies 7, no. 2 (Spring 2000): 488.
} 
to strike defined as caring for each other and acting in solidarity. In Azoulay's words, "Going on strike is to claim one's right not to engage with destructive practices, not to be an oppressor and perpetrator, not to act according to norms and protocols whose goals were defined to reproduce imperial and racial capitalist structures." ${ }^{12}$ By engaging visitors in collective activities that foster a sense of community and a shared interest in caring for each other and for the world, empowerment at the museum takes place from below and emphasizes the need to imagine different ways of being. As such, signs hanging from the museum's ceiling read "No Wall," "Stop Repeating History," and "Otro Mundo es Posible" (Fig. 4). ${ }^{13}$

In addition to the numerous artworks, the museum had extensive labels that guided viewers through the exhibit. The exhibit clearly underscored our right not to act against others, in line with Azoulay's exhortation not to be perpetrators, and visualized a nonhegemonic view of citizenship, as described by Bosniak, based on affective ties vis-à-vis birthright citizenship. ${ }^{14}$ Saskia Sassen has similarly reflected on alternative definitions of citizenship by examining what she terms the "global city." Sassen describes the global city as "a partly denationalized space that enables a partial reinvention of citizenship." ${ }^{15}$ According to Sassen, in the global city, "citizens" come together based on their interests in human rights, justice, and equality as opposed to notions such as the modern nation state. Aram Han Sifuentes's work underscores these rights and ideas as well.

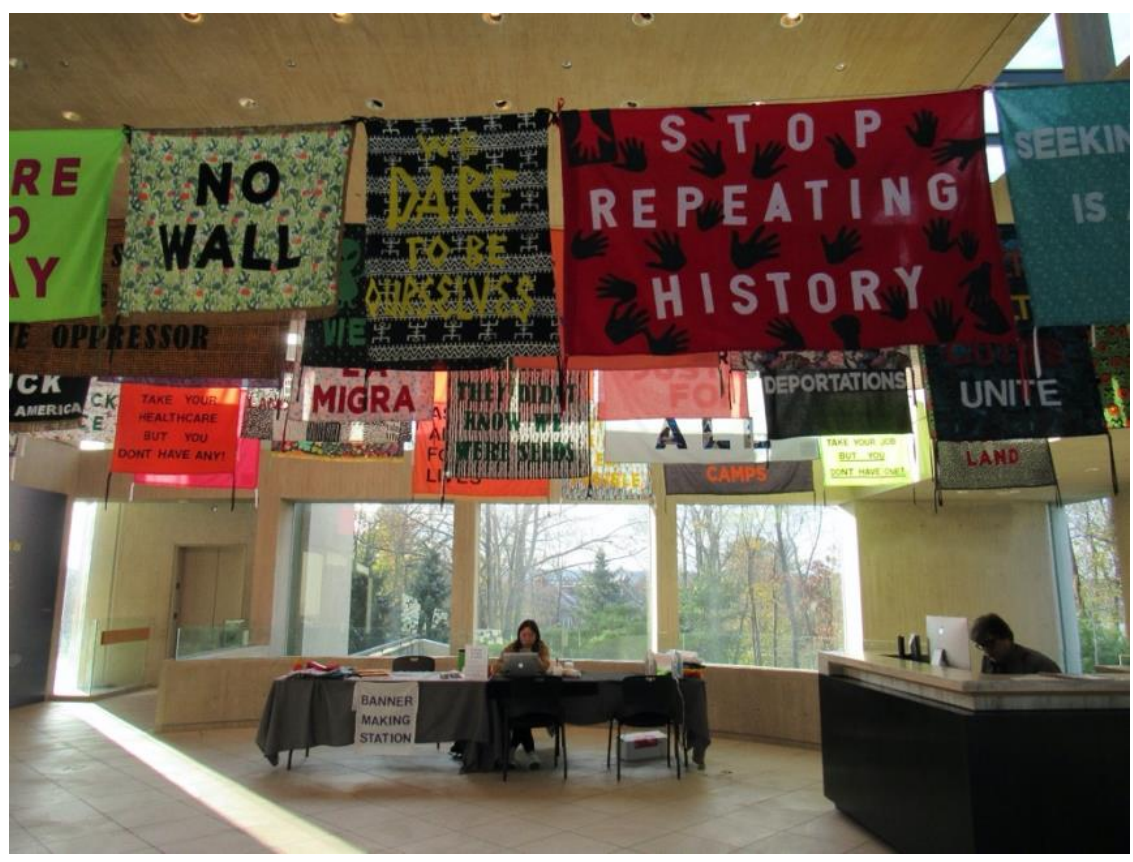

Figure 4 Aram Han Sifuentes, Protest Banner Lending Library, 2016-ongoing. Felt and fusible web on fabric (Photo: Author)

\footnotetext{
12 Azoulay, Potential History, 157-158.

13 "Otro mundo es posible" can be translated as "a different world is possible."

14 Bosniak, "Citizenship Denationalized," 479. Despite the exhibit's strong emphasis on pro-immigration policies and its criticism of nationalisms, a disclaimer was visible stating, "the works on display represent the viewpoints of each individual artist and are not an expression of the official views of Cornell University."

15 Saskia Sassen, "The Repositioning of Citizenship: Emergent Subjects and Spaces for Politics," CR: The New Centennial Review 3, no. 2 (Summer 2003): 44.
} 
Printed in Spanish, English, and Arabic, Messages to My Neighbors (2016-ongoing) by Sifuentes consists of three hanging white banners featuring each of these languages surrounding a bulky column (Fig. 5). Messages to My Neighbors presents specific guidelines to empower, inform, help, and support immigrants who are considered "non-U.S. citizens." In Messages to My Neighbors, Sifuentes explains to those who have not been granted legal citizenship status how best to protect themselves from the injustices of government agencies, such as the US Immigration and Customs Enforcement office, as well as from deportation. Sifuentes warns, "Do not open the door," "Do not answer any questions - you have a right to remain silent," and "Do not sign anything." Sifuentes's artwork thus further makes the case for denationalized citizenship and a reinvention of the term to emphasize affective ties and undermine normative legal categorizations.

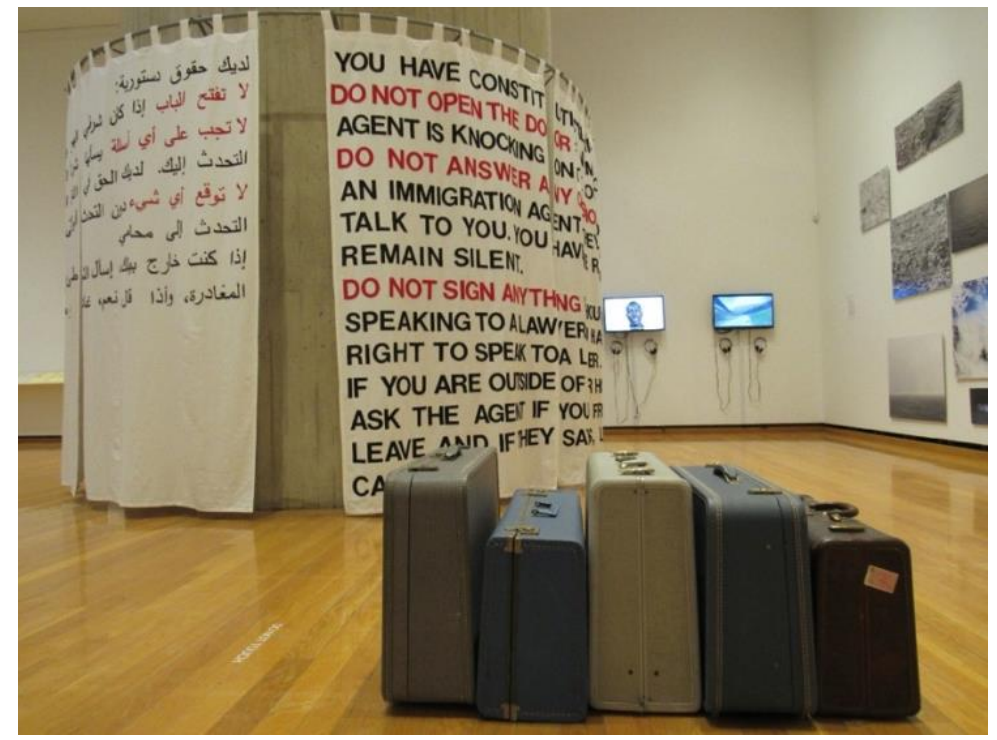

Figure 5 Aram Han Sifuentes, Messages to My Neighbors (2016-ongoing). Fabric, felt, and fusible web (left); Peng! Collective, Fluchthelfer.in Become an Escape Agent (2015). Two single-channel videos (back center); Dawit L. Petros, Historical Rupture (detail) from the series The Stranger's Notebook (2016-17).

Archival color pigment prints (back right); and Zoe Leonard, Untitled (2001), five suitcases (front). Installation view of how the light gets in at Herbert F. Johnson Museum of Art, Cornell University, Ithaca (Photo: Author)

Another theme included the institutionalization of migration. Yinka Shonibare's The American Library Collection (Politicians) (2017) presented 213 books with the names of political leaders who have voted for or against the opening of borders, providing or denying citizenship status and rights to people. Inscribed in gold, the names Ilhan Omar, Nancy Pelosi, Donald Trump, and Marco Rubio were displayed on the book's spines. In addition to the immigration debates were references to the passport-a modern invention of the nation-state. As Reece Jones explains, prior to World War I, passports were only used during war time, and the United States did not have a systematic passport requirement until after World War II. ${ }^{16}$ Sobia Ahmad's Small Identities (2017-ongoing) presents black-and-white passport-like images on tiles (Fig. 6). On more than fifty tiles, Ahmad contests the notion of the passport to (dis)identify the subject by eliminating biographical data such as name, country of birth, or birthdate. Ahmad shows slightly blurred portraits of Muslim immigrants and, according to the museum's label, she left many of the tiles blank due to the subjects' reluctance to be photographed in fear of retaliation and xenophobia.

16 Reece Jones, Violent Borders: Refugees and the Right to Move (London: Verso, 2017), 85. 


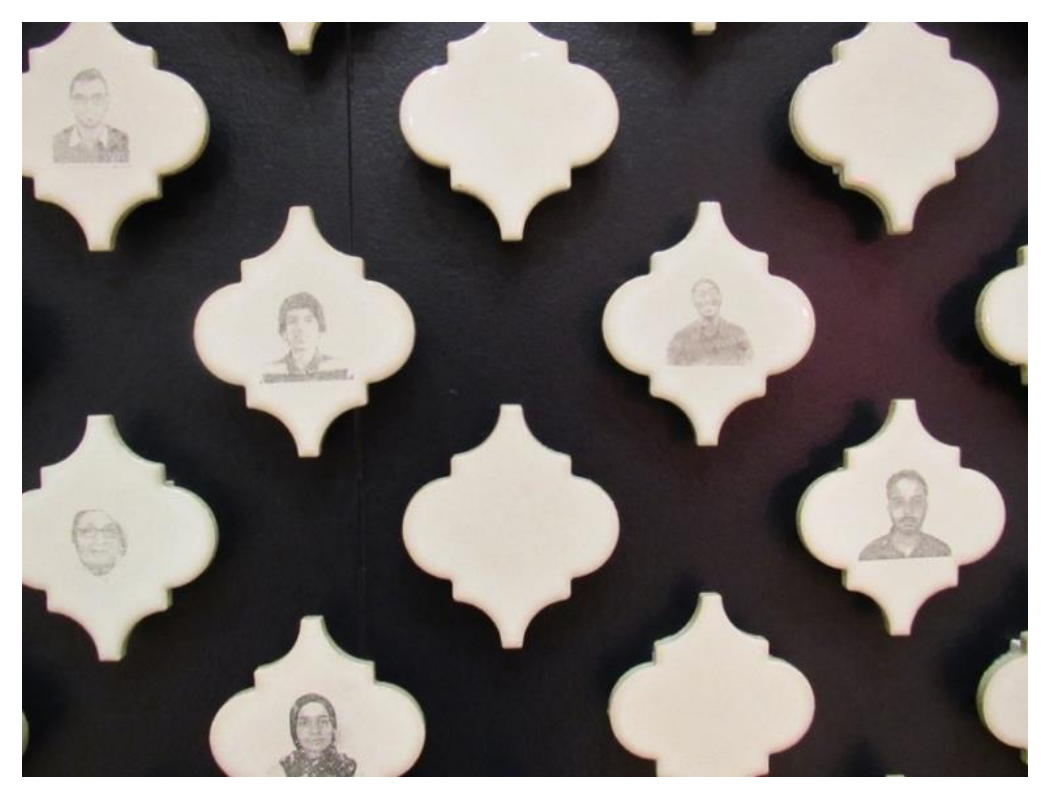

Figure 6 Sobia Ahmad, detail from Small Identities (2017-ongoing). Photo transfers on ceramic. Installation view of how the light gets in at Herbert F. Johnson Museum of Art, Cornell University, Ithaca (Photo: Author)

A variety of artworks in how the light gets in offered criticism of bare life. Defined by Giorgio Agamben as "a life that may be killed without the commission of homicide," bare life refers to lives that are disregarded, marginalized, and subject to murder without punishment for the perpetrators. ${ }^{17}$ In The Wine Dark Sea (2016), Hew Locke exhibits twelve hanging ships made of a variety of materials that included fabric, bamboo, and plastic (Fig. 7). Among them were a schooner, a fishing boat, and a tugboat. The precarious ships highlight the fragility of these vessels as well as that of the lives who embark on them in search of better futures. Locke's installation is a potent reminder of the thousands of people who have perished at sea with no consequences for perpetrators in a society that regards the lives of economic migrants and refugees as expendable. Locke's The Wine Dark Sea complements the narrative of travel and border crossing in Manaf Halbouni's Nowhere is Home as well as that of Forensic Oceanography's Liquid Traces -The Left-to-Die Boat Case (2014), located next to Locke's installation in a darkened room. The video, Liquid Traces -The Left-to-Die Boat Case, shows the tragic story of 72 passengers left to die in the Mediterranean Sea in $2011 .{ }^{18}$ In this video, Forensic Oceanography exposes transnational culpability as governments from France, Italy, and Spain, among others, failed to assist the stalled boat and rescue the dying passengers. The video explains how a hyper-surveilled area became a death trap due to neglect and the concept of bare life that allows impunity and the continuous loss of people. ${ }^{19}$

\footnotetext{
17 Agamben, Homo Sacer, 159.
}

18 Achille Mbembe offers a resolute critique of Europe's process of borderization. Mbembe writes, "Who claims the largest number of skeletons and the largest marine cemetery in this century? Again, it is Europe! The greatest number of deserts, territorial and international waters, channels, islands, straits, enclaves, canals, rivers, ports, and airports transformed into iron curtain technologies? Europe!..." Achille Mbembe, Necropolitics, 102.

19 There were only nine survivors. Forensic Oceanography's Liquid Traces -The Left to Die Boat is available online through their website (https://forensic-architecture.org/investigation/the-left-to-dieboat). For more on the border apparatus and a mobile border, read Todd Miller, Empire of Borders: The Expansion of the U.S. Border Around the World (London: Verso, 2019). For a discussion on ocean borders and migratory necropolitics, read Laura Lo Presti, who reminds us that from 2014 to 2020, 70 percent of migrant deaths occurred at sea; see "Like a Map Over Troubled Water: (Un)mapping the Mediterranean Sea's Terraqueous Necropolitics," eflux journal \#109 (May 2020). 


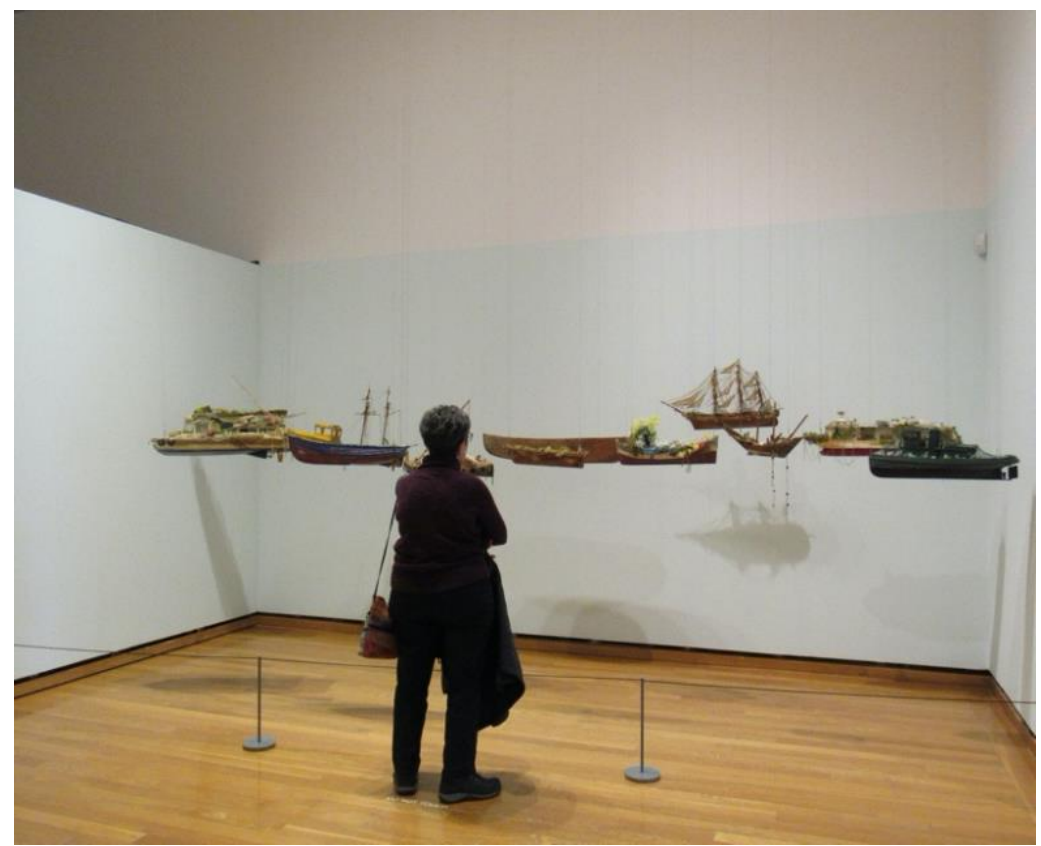

Figure 7 Hew Locke, The Wine Dark Sea (2016). Wood, metal, fabric, string, bamboo, paint, and plastic. Installation view of how the light gets in at Herbert F. Johnson Museum of Art, Cornell University, Ithaca (Photo: Author)

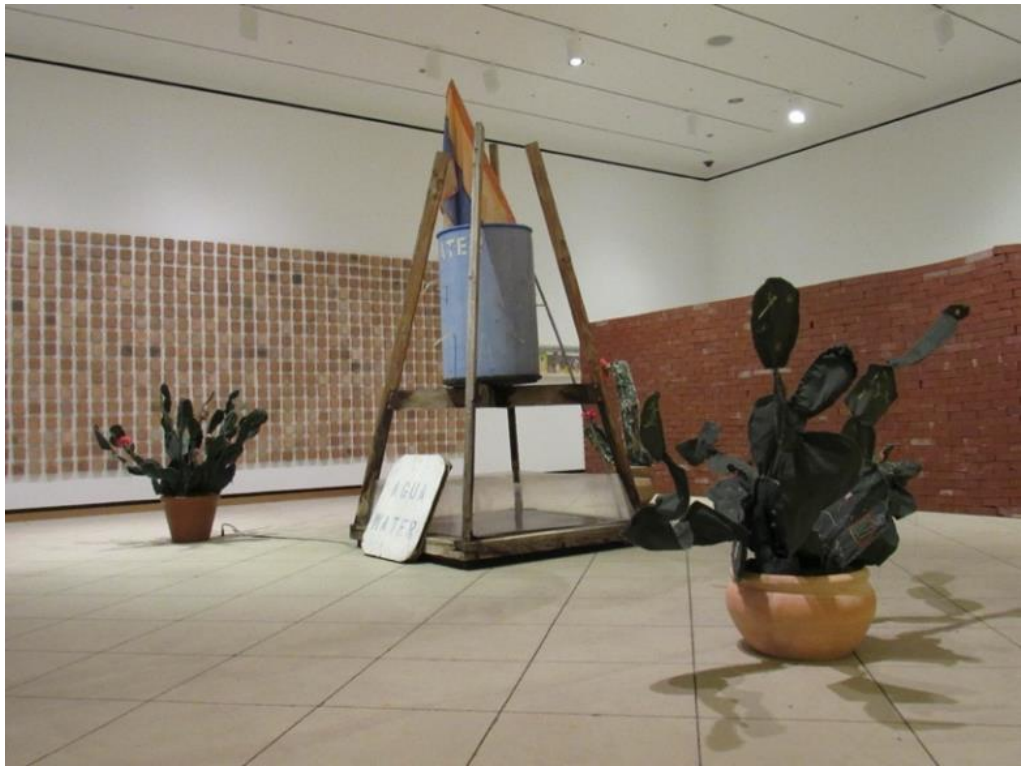

Figure 8 ,Guillermo Galindo, Fountain of Tears/Fuente de Lágrimas (2014). Wood, iron plate, barrel, pump, plastic tubes, water, and beacon flag (center); Margarita Cabrera, Space in Between -Nopal \# 2 (2012) (left), Space in Between -Saguaro (Maria Lopez) (2010) (back), and Nopal con Tunas \# 2 (2006) (front). Fabric, copper, wire, and terra cotta pots; Teresa Margolles, La Gran América (2017). Fired clay (back left); Jorge Méndez Blake, Amerika (2019). Bricks and edition of Amerika by Kafka (back right). Installation view of how the light gets in at Herbert F. Johnson Museum of Art, Cornell University (Photo: Author) 
Similarly, Guillermo Galindo's Fountain of Tears/Fuente de Lágrimas (2014) communicates the structural violence of borders and migratory policies (Fig. 8). Galindo's pyramidal structure in the center of another gallery contained a blue water barrel from which drops of water fell onto a metal plate. Its sign, "agua/water," reminds viewers how precious this resource is for those found in the middle of the ocean or in the desert attempting to enter nations without being caught. The makeshift structure acknowledges that borders will be crossed despite an extensive global apparatus that enforces security and surveillance through technology and physical barriers.

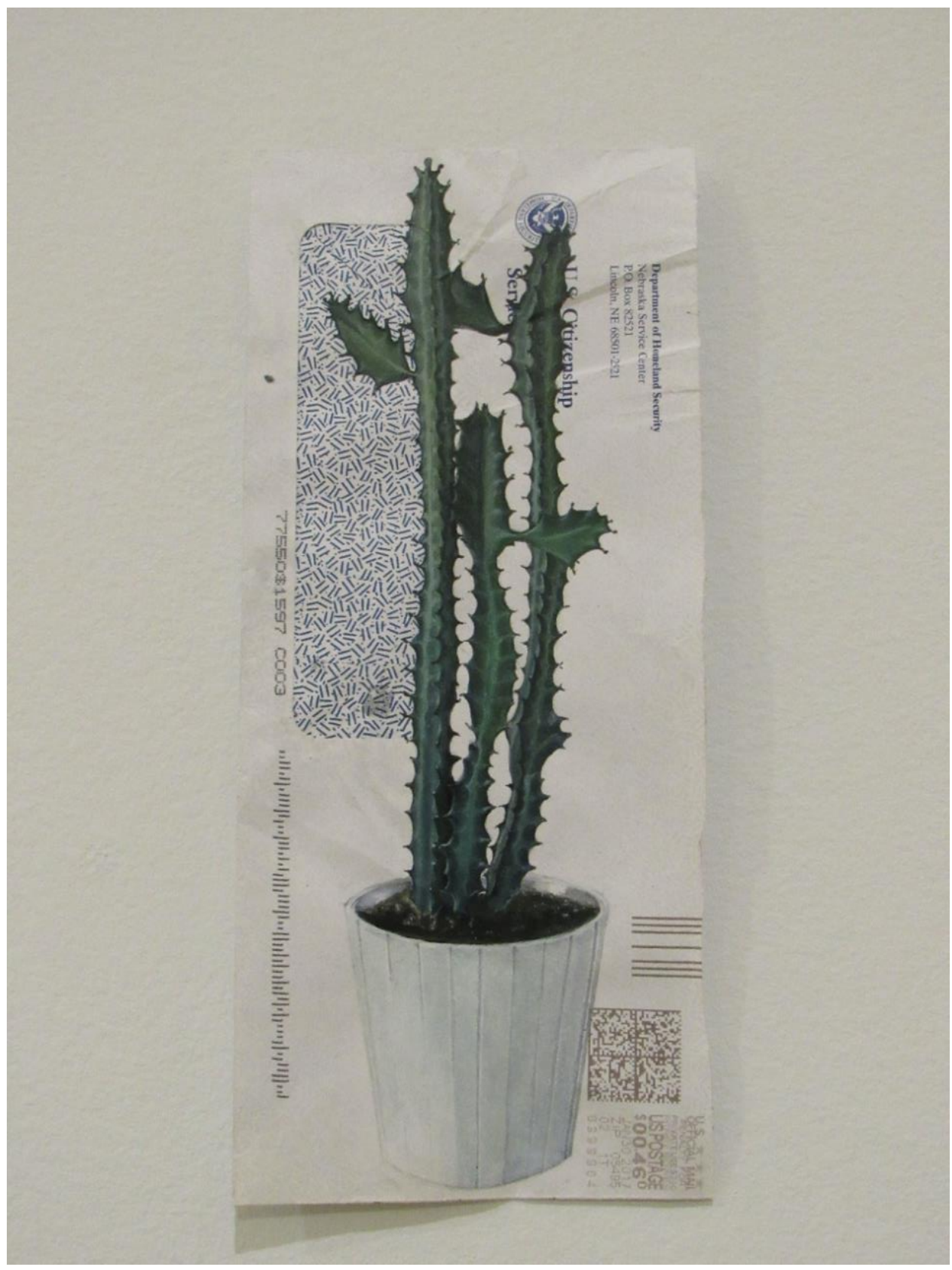

Figure 9 Fidencio Fifield-Pérez, detail from Dacaments 1-17 (2017-2019). Acrylic on paper (Photo: Author) 
Esperanza Mayobre's Welcome to the Yunaited Stai addressed the main themes of the exhibit on a mat inscribed with the words "Welcome to the Yunaited Stai" (2012). Visitors could step on the mat in a way one would step on any other doormat, but inside the museum this gesture undermines both the sanctity of the artwork and its "welcoming" message. One is prompted to ask, who is welcomed? And where and when is one welcomed? Mayobre's mat introduced viewers to a room that displayed mail correspondence between Fidencio Fifield-Pérez and his lawyer. Portraying a variety of plants, the seventeen collected envelopes are evidence of a long bureaucratic process endured by those seeking legal recognition in a country (Fig. 9). The worn envelopes in Dacaments 1-17 (2017-2019) show not only traces of time, but also a variety of locations in which the artist found himself through the arduous and time-consuming process of applying for legal citizenship (Fig. 10).

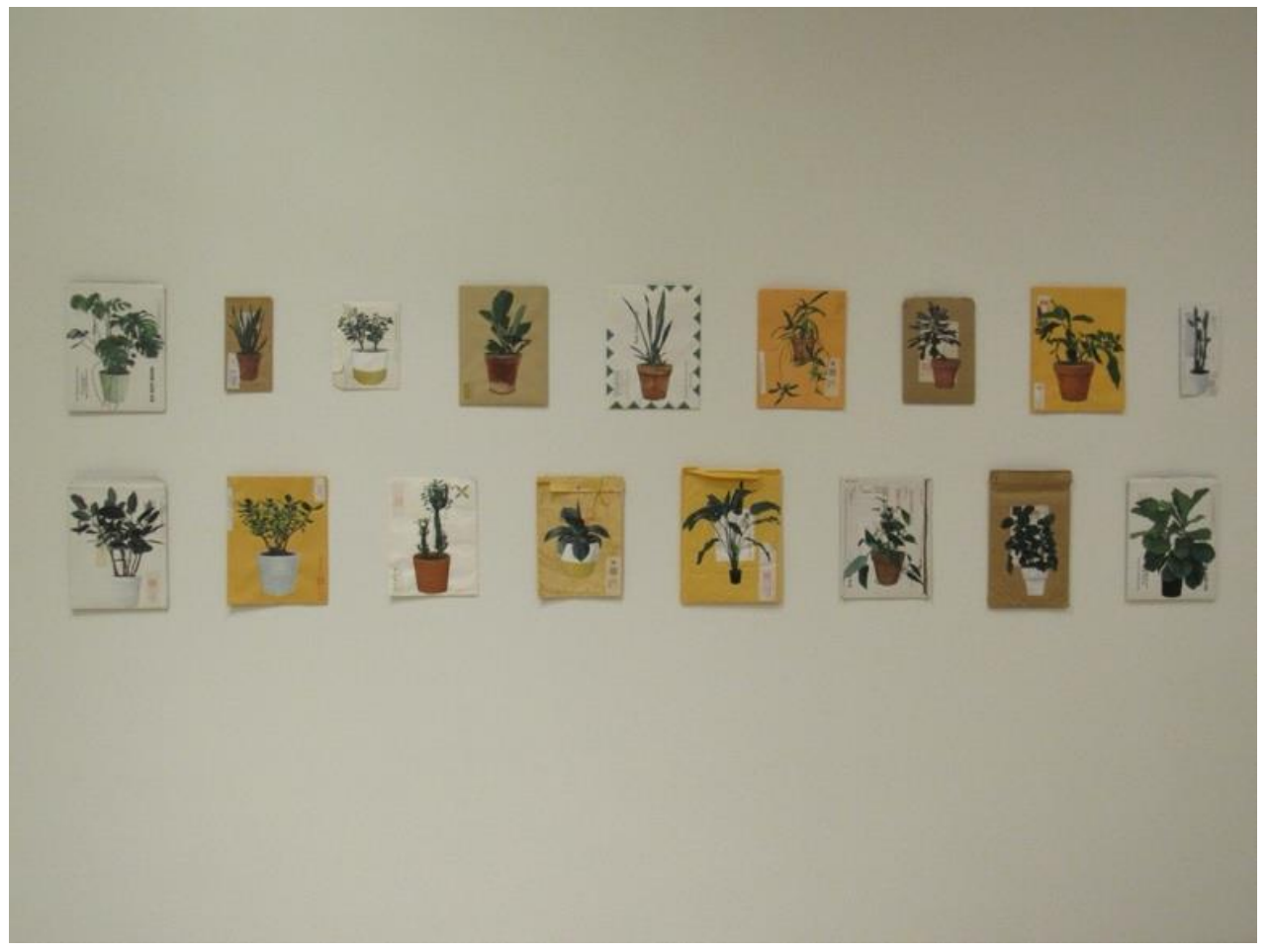

Figure 10 Fidencio Fifield-Pérez, Dacaments 1-17 (2017-2019). Acrylic on paper (Photo: Author)

The female body was another theme threaded through how the light gets in. While it is certain that thousands of women and their children are often on the move and are subjected to an innumerable number of abuses, a half-clothed figure showing her breasts to the viewer might have confused viewers. ${ }^{20}$ In Boob Gold (2018), Hayv Kahraman, according to the gallery label, conveys a strong individual who is empowered and reflects no intimidation or victimhood. Yet the imagery and the juxtaposition of artworks in this crammed hallway diminished the powerful messages of exile, a plurality of citizenships, and the idea of social justice for all (Fig. 11).

The quantity of artists and artworks in how the light gets in was overwhelming for any viewer, yet the diversity of media and viewpoints made this a powerful show. how the light gets in reminds us, as Leonard Cohen sang in his 1992 song "Anthem," that "there is a crack

20 For a journalistic account on the violence perpetrated against women who cross borders "illegally" for a variety of reasons, read Oscar Martínez's book The Beast, where he writes about the "bra tree myth" along the Mexico-US border where women migrants are raped and their clothes displayed as trophies. Oscar Martinez, The Beast: Riding the Rails and Dodging Narcos on the Migrant Trail (New York: Verso, 2013), 161-183. 
in everything and that's how the light gets in." 21 As environmental disasters, economic crises, authoritarian governments, and wars force thousands of people out of their homes and drive them to risk their lives, we must rethink not only the nation, but also the concept of citizenship as tied to the nation-state. Moving beyond the binary of citizen/noncitizen and committing to a denationalized form of the term that is more plural and open are long overdue. The invitation is to recognize our common humanity, to practice solidarity, and to exercise our rights not to act against others. As Azoulay and Butler explain, we should strive to act as co-citizens and help one another in the name of equality and freedom in a shared world. ${ }^{22}$

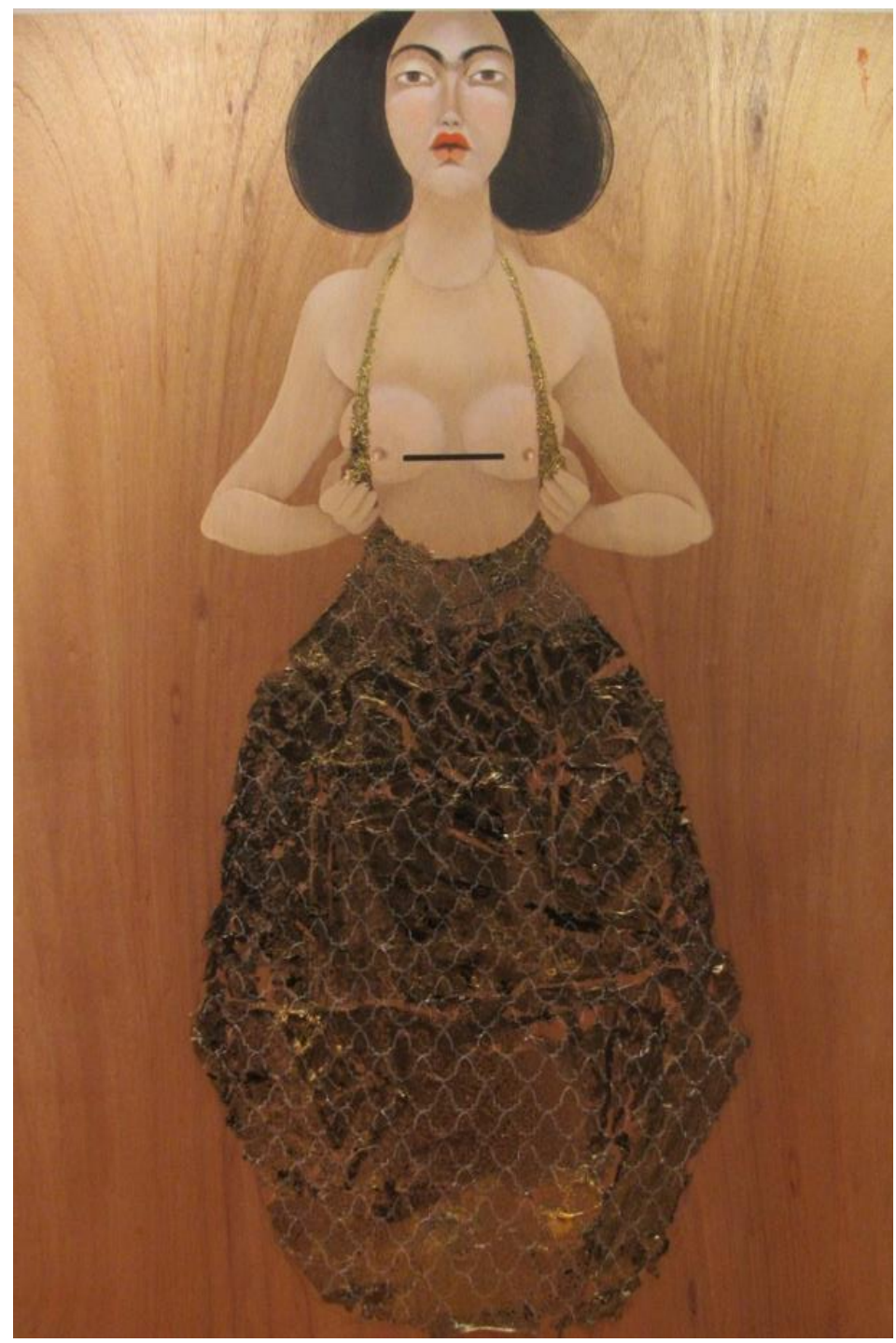

Figure 11 Hayv Kahraman, Boob Gold (2018). Oil on wood (Photo: Author)

\footnotetext{
21 "how the light gets in," At the Johnson: The Member's Newsletter of the Herbert F. Johnson Museum of Art, Fall 2019, 5.

22 I thank the Department of History of Art and Architecture at the University of Pittsburgh for funding my research through the Dean's Research Travel Fund (Fall 2019). I extend my heartfelt gratitude to Claire Ptaschinski, Emi Finkelstein, and Katie Loney, editors of Contemporaneity: Historical Presence in Visual Culture: Moving Across/Through Cultures. I am also indebted to Andrea Potochniak, editorial manager at the Herbert F. Johnson Museum of Art, for her kindness and assistance with the images' captions and her editorial advice.
} 
(c) $\mathbf{E Y}$ New articles in this journal are licensed under a Creative Commons Attribution 4.0 United States License.

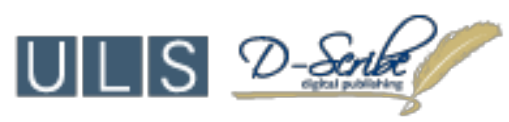

This journal is operated by the University Library System of the University of Pittsburgh as part of its D-Scribe Digital Publishing Program, and is co-sponsored by the University of Pittsburgh Press. 